\title{
Expression of Thrombospondin in the Adult Nervous System
}

\author{
JOHN R. HOFFMAN, VISHVA M. DIXIT, AND K. SUE O'SHEA \\ Departments of Anatomy and Cell Biology (J.R.H., K.S.O.) and Pathology (V.M.D.), \\ The University of Michigan, Ann Arbor, Michigan 48109
}

\begin{abstract}
Thrombospondin (TSP) is an extracellular matrix molecule that has been previously associated with neural development and neurite outgrowth in vitro. Little is known, however, about the expression of TSP in the adult nervous system. In this study, TSP localization was examined in nervous tissue from adult mouse, goldfish, newt, and adult and juvenile Xenopus. TSP was associated with neurons in the brains of all species examined. TSP was present in central nerve tracts capable of regeneration, such as the goldfish, Xenopus, and newt optic nerves, but was absent from tracts not capable of regeneration, such as the mouse optic nerve. TSP was also present in the neuropil of goldfish and newt spinal cord, but was restricted to motor neurons in mice and adult Xenopus. In addition, TSP was observed in sciatic nerves of mice, Xenopus, and newt. These results indicate a correlation between the presence of TSP and the potential for successful nerve regeneration across a wide range of animal classes.

(c) 1994 Wiley-Liss, Ine.
\end{abstract}

Key words: extracellular matrix, frog, goldfish, mouse, regeneration

It well known that mammalian peripheral nerves are capable of regeneration, but mammalian central nervous system (CNS) tracts do not regenerate (Ramón y Cajal, '28). In fish and urodele amphibia, both central and peripheral nerve regeneration occurs (Windle, '56; Clemente, '64). Anuran amphibia are capable of CNS and peripheral nervous system (PNS) regeneration as juveniles, but as adults only optic nerve regeneration occurs (Clemente, '64; Bohn et al., '82); spinal cord regeneration is unsuccessful. A crucial question in the field of neurobiology is the cellular and molecular basis of the differential regenerative potential between central and peripheral nervous systems, and across species.

Explanations for these differences include variable glial response (Wujek and Reier, '84; Reier and Houle, '88), the presence of inhibitory factors (Schwab, '91), or lack of supportive factors in the mammalian CNS (Liesi, '85a,b). It is likely that the combination of supportive conditions and absence of inhibitors may ultimately be required for regeneration to succeed.

Thrombospondin (TSP) is a $420 \mathrm{kDa}$ trimeric glycoprotein component of the extracellular matrix (ECM), originally identified as a component of the platelet alpha granule released on activation (Baenziger et al., '71). TSP has since been shown to be involved in cell attachment (Varani et al., '86; Roberts et al., '87), migration (Majack et al., '86; $O$ 'Shea et al., '90), and neurite outgrowth (Neugebauer et al., '91; O'Shea et al., '91; Osterhout et al., '92). TSP may act in vivo by organizing the ECM via binding of other ECM components, including: type I collagen (Lahav et al., '82), type V collagen (Mumby et al., '84), laminin (Mumby et al., '84), fibronectin (Lahav et al., '82, '84), glycosaminoglycans (Dixit et al., '84; Lawler et al., '85), plasminogen (Silverstein et al., '84), and tissue- and urokinase-type plasminogen activators (Silverstein et al., '86). TSP has been sequenced in the human (Lawler and Hynes, '86), mouse (Laherty et al., '92), chicken (Lawler et al., '91), and Xenopus (Urry et al., '91), and the functional domains of TSP show a high degree of conservation across species. Although the distribution of TSP is developmentally regulated in the mouse nervous system (O'Shea and Dixit, '88), little is known about the expression pattern of TSP in adult nervous tissue. This study examines the pattern of TSP expression in the nervous systems of mice, goldfish, frogs, and newts.

\section{MATERIALS AND METHODS Tissue}

Species used in this study were adult CD-1 mice (Mus musculus), adult goldfish (Carassius auratus), adult frogs (Xenopus laevis), adult newts (Taricha torosa and Taricha

Accepted August 21, 1993

John R. Hoffman's current address is Department of Anatomy and Neurobiology, Medical College of Pennsylvania, Philadelphia, PA 19129.

Address reprint requests to Dr. K. Sue O'Shea, Dept. of Anatomy and Cell Biology, University of Michigan, Ann Arbor, MI 48109-0616. 
rivularis), and premetamorphic juvenile frogs (Xenopus laevis) at the forelimb bud stage. Mice were anesthesized with methoxyfluorane (Metofane, Pitman-Moore, Washington Crossing, NJ), while goldfish, frogs, and newts were anesthesized with MS-222 or submerged in ice water; then brain, spinal cord, optic nerve, and sciatic nerves were removed and rapidly frozen in Optimal Cutting Temperature embedding compound (OCT; Miles Laboratories, Inc., Elkhart IN) in hexane cooled over an acetone-dry ice slurry. Ten micron frozen transverse and sagittal sections were collected on $0.1 \%$ poly-L-lysine coated slides and stored at $4^{\circ} \mathrm{C}$ until processing for immunocytochemistry. For the survey of brain tissue, one coronal section was collected every $200 \mu \mathrm{m}$; in brains cut sagittally, one section was collected every $200 \mu \mathrm{m}$ (newt, frog), $300 \mu \mathrm{m}$ (goldfish), or $400 \mu \mathrm{m}$ (mouse).

\section{Antibody specificity}

The specificity of the rabbit anti-human TSP antibodies used in these experiments was confirmed by Western blotting. The anti-TSP antibody has previously been shown to be specific for mouse TSP (O'Shea and Dixit, '88). Brain tissue from each species was frozen in liquid nitrogen. Proteins were extracted from the tissue, run on a polyacrylamide gel, transferred to nitrocellulose, and detected by means of a standard enhanced chemoluminescence kit (ECL; Amersham Corp., Arlington Heights, IL). Purified platelet TSP was employed as a control.

\section{Immunocytochemistry}

Selected sections were washed in phosphate-buffered saline (PBS), and nonspecific antibody binding was blocked using normal goat serum (1:20), followed by rabbit antihuman TSP primary antibody $(1: 20)$ or normal rabbit serum. Antibody binding was visualized either by using an fluorescein isothiocyanate (FITC)-conjugated goat antirabbit IgG secondary antibody (1:20, Sigma Chemicals, St. Louis, MO) or using a strepavigen-alkaline phosphataselabeled secondary antibody (StrAviGen Super Sensitive Universal Immunostaining kit, BioGenex Labs., San Ramon, CA), with a fast red chromogen. Slides exposed to the FITC-labeled secondary antibody were coverslipped with glycerol containing $0.1 \%$ phenylenediamine and then viewed and photographed in a Leitz Aristoplan microscope fitted with an L-1 fluorescence cube. Slides stained with the supersensitive kit were counterstained with hematoxylin, coverslipped with Crystal Mount (Biomeda Corp., Foster City, CA), and then examined using transmitted light.

\section{RESULTS \\ Western blotting}

The rabbit anti-human TSP antibody used in these studies reacts specifically with TSP in each of the species examined. The specificity of this antibody for mouse TSP has been shown previously (O'Shea and Dixit, '88). The results of an immunoblot of whole brain proteins of adult goldfish, newt, and Xenopus indicate that the rabbit antihuman TSP antibodies detect a protein that comigrated with purified human platelet TSP (Fig. 1A,B). Preimmune serum showed no reactivity to goldfish, newt, or Xenopus proteins (Fig. 1C).

\section{Brain}

Brain regions were identified based on previously reported criteria for the mouse (Sidman et al., '71), goldfish (Peter and Gill, '75; Easter et al., '78), frog (Kemali and Braitenberg, '69; Opdam et al., '76; King and Custance, '82), and newt (Herrick, '48; Roth, '87), and analogous structures were compared (Romer and Parsons, '77; Wake, '79; Sarnat and Netsky, '81). The results of studies of comparative brain regions are summarized in Table 1 , and sample regions are illustrated for mouse (Fig. 2), goldfish (Fig. 3), Xenopus (Fig. 4), and newt (Fig. 5). Cytoplasmic immunoreactivity was easily distinguished from cell surface staining, in which immunoreactivity formed a dense halo surrounding the cell.

The olfactory bulb of all species examined consistently expressed high levels of TSP immunoreactivity (Figs. 2B, $3 \mathrm{~B}, 4 \mathrm{~B}, 5 \mathrm{~B})$. The neuropil of the mouse granule cell layer stained less intensely than the external plexiform layer, in contrast to the frog, newt, and goldfish, in which the granule cell layer exhibited higher levels of TSP immunoreactivity than the external plexiform layer.

In the cerebral hemispheres in a region corresponding to the subpallium, TSP was present in neurons but absent from the white matter of the caudate putamen. Analogous regions in the goldfish, frog (Fig. 4C), and newt (Fig. 5C) exhibited TSP immunoreactivity both in the neuropil and associated with neurons.

In the mouse hippocampus, the dentate molecular layer and neuropil was negative for TSP, the hilus of dentate

Abbreviations

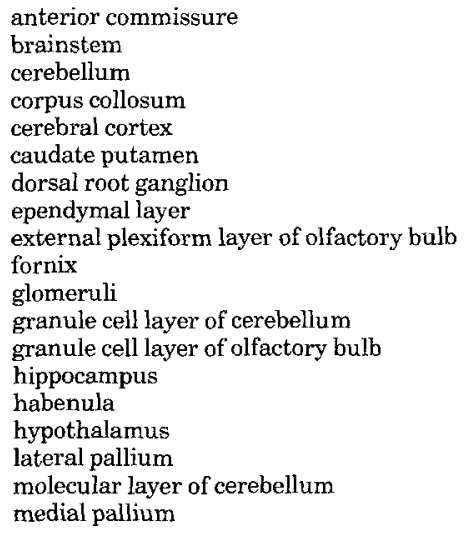

$\begin{array}{ll}\text { mr } & \text { mammillary region } \\ \text { nhy } & \text { neural hypophysis } \\ \text { ob } & \text { olfactory bulb } \\ \text { olt } & \text { olfactory tract } \\ \text { ot } & \text { optic tract } \\ \text { p } & \text { pons } \\ \text { phy } & \text { primary lobe of hypophysis } \\ \text { pn } & \text { peripheral nerve } \\ \text { po } & \text { nucleus preopticus } \\ \text { pvl } & \text { periventricular layer } \\ \text { scg } & \text { stratum centrale griseum } \\ \text { sm } & \text { stria medullaris } \\ \text { so } & \text { stratum opticum } \\ \text { sp } & \text { subpallium } \\ \text { th } & \text { thalamus } \\ \text { tl } & \text { torus longitudinalis } \\ \text { to } & \text { optic tectum } \\ \text { V } & \text { ventricle } \\ \text { wm } & \text { white matter of the cerebellum }\end{array}$




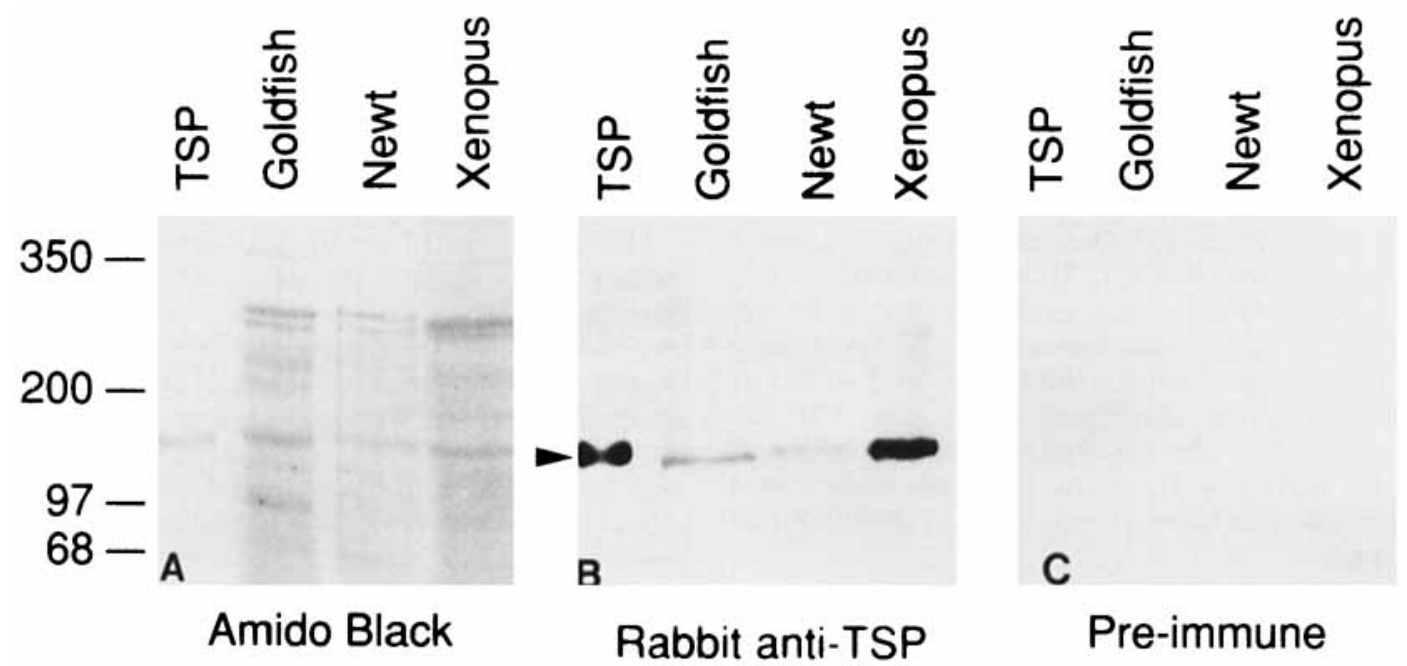

Fig. 1. Immunoblot illustrating the specificity of the rabbit antihuman thrombospondin (TSP) antibody. Purified human platelet TSP (lane 1, from left), and whole brain protein from goldfish (lane 2), newt (lane 3), and frog (lane 4) were stained with Amido Black (A), and

gyrus was slightly positive, and the granule layer was intensely positive (Fig. 2D). In contrast, the goldfish (Fig. 3C), frog, and newt hippocampal neuropil was intensely positive. Neurons of the frog hippocampus were also TSP positive.

In the diencephalon and mesencephalon of all species, TSP immunoreactivity was associated with neurons, with less staining of the white matter. Newt neurons typically exhibited less immunoreactivity than other species, while in both the frog and goldfish staining of the neuropil was more intense.

The cerebellum of different species shows marked diversity in size and complexity, being small in the frog and newt, but very large in the goldfish. Complexity ranges from the simple bilayer in the newt to the multilayered structure of the mouse. In the goldfish, frog, and newt, TSP immunoreactivity was present in the neuropil of the molecular layer, and surrounding granule neurons of the cerebellum (Figs. $3 \mathrm{E}, 5 \mathrm{D})$. In the mouse, TSP immunoreactivity was present in the molecular layer, and in the granule cell layer. Scattered neurons in the mouse molecular layer were slightly TSP positive, as were the cell bodies of protoplasmic astrocytes (Fig. 2E).

CNS tracts exhibited considerably greater species differences. In the mouse, the anterior commissure, corpus callosum, fornix, stria medullaris, and mammilothalamic tract contained little TSP immunoreactivity. Conversely, tracts in the goldfish such as the optic tract, horizontal commissure, and medial Iongitudinal fasiculus exhibited varying degrees of TSP immunoreactivity. There was little difference between the levels of TSP immunoreactivity in the neuropil and CNS tracts in the frog and newt

In the mouse spinal cord, TSP was present in the cell bodies of the ventral horn (motor neurons) cells and inside the axons of the motor neurons (Fig. 6A,B), but no TSP immunoreactivity was observed in the neuropil surrounding the motor neurons or associated with the glial cells of the cord. TSP immunoreactivity was observed at high levels surrounding and within the cells of the dorsal root ganglia (DRG). There was some nonspecific staining of the gray matter accounting for the diffuse fluorescence in the gray matter of the cord.

In the goldfish spinal cord, TSP immunoreactivity was observed at very high levels surrounding the ependymal cells lining the central canal and in the neuropil (Fig. 6C). TSP was also observed in the cell bodies of the ventral horn cells, in radial glia, and at the glia limitans (Fig. 6D).

In the adult Xenopus spinal cord, TSP was present in the pia mater, and in peripheral nerves leaving the spinal cord, but was largely absent from the cord itself (Fig. 6E). Upon examination at higher magnification, TSP was observed in some glial cell bodies (Fig. 6F) and random neurons (probably motor neurons as identified by their nuclei). The frog provides an interesting model for nerve regeneration studies as the juvenile frog is capable of spinal cord regeneration, which is lost following metamorphosis. TSP was present at high levels in the spinal cord of the frog tadpole (Fig. 7A,B), but was virtually absent from the spinal cord of the adult frog (Fig. 7C,D).

In the newt spinal cord, TSP was present in the pia mater surrounding the spinal cord and surrounding the cells of the DRG (Fig. 6G). It was associated with the cells within the gray matter and was diffusely present throughout the white matter (Fig. 6H).

\section{Optic nerve}

In the mouse optic nerve, TSP immunoreactivity was virtually absent; a very low level was associated with scattered glial cell bodies. There was a limited amount of TSP in the pia-arachnoid (Fig. 8A). In the goldfish optic nerve, TSP was present in higher levels than the mouse optic nerve, where it was found largely within the connective tissue septae surrounding nerve fasicles, as well as in the pia-arachnoid layer (Fig. 8B). In adult Xenopus, TSP was present in glial cell bodies, diffusely throughout the nerve, and in the pia-arachnoid layer (Fig. 8C). In the juvenile Xenopus optic nerve, TSP was present at higher 

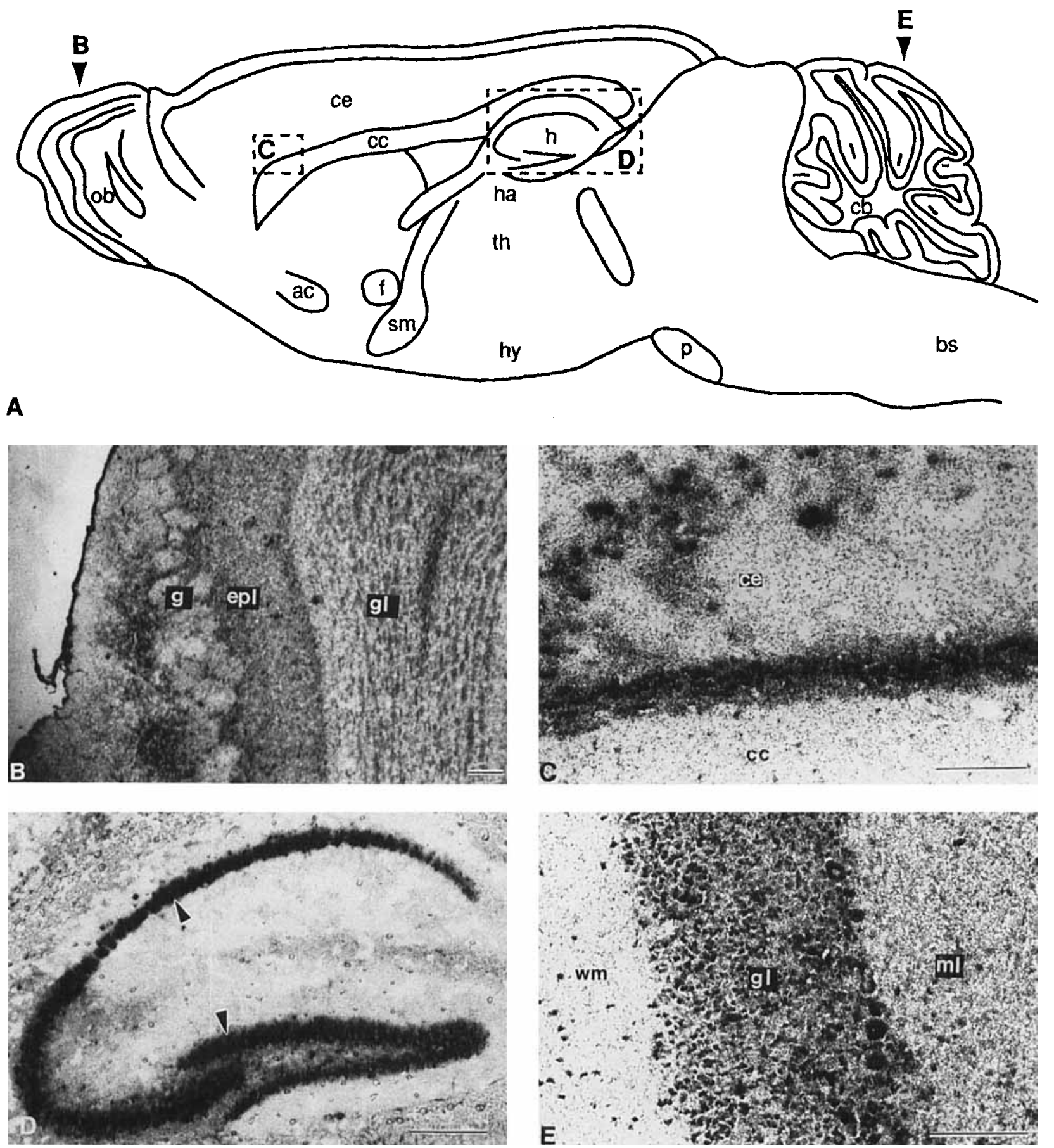

Fig. 2. TSP localization in the mouse nervous system using a strepavigen-alkaline phosphatase conjugated secondary antibody. A: Diagram of a sagittal section of the mouse brain (after Sidman et al., 1971). Dashed boxes indicate regions of the corresponding photomicrographs, and arrowheads indicate levels of the coronal sections. B: In the olfactory bulb, intense TSP immunoreactivity was present in the neuropil of the external plexiform layer (epl), outlining individual glomeruli (g), and in a concentric pattern within the granule cell layer

levels than the adult nerve, appearing in connective tissue septae (Fig. 8E) in a pattern similar to that observed in the goldfish. In the newt optic nerve, TSP was present in the pia-arachnoid and throughout the optic nerve (Fig. 8D). (gl). C: In the cerebral cortex there was diffuse immunoreactivity in the deep cortical layers, and absence of immunoreactivity in superficial cortex (ce) and the fiber tracts of the corpus callosum (cc). D: In the hippocampus, there was intense staining restricted to the granular layer (arrowheads). E: In the mouse cerebellum, light staining was present in the molecular layer (ml); there was also slight staining of the granule cell layer (gl), but little in the white matter $(\mathrm{wm})$. Scale bars $=$ $100 \mu \mathrm{m}$.

\section{Sciatic nerve}

In the mouse sciatic nerve, TSP was observed within axons, in the Schwann cell endoneurium, perineurium, and the epineurium (Fig. 8F). There was a great deal of TSP 


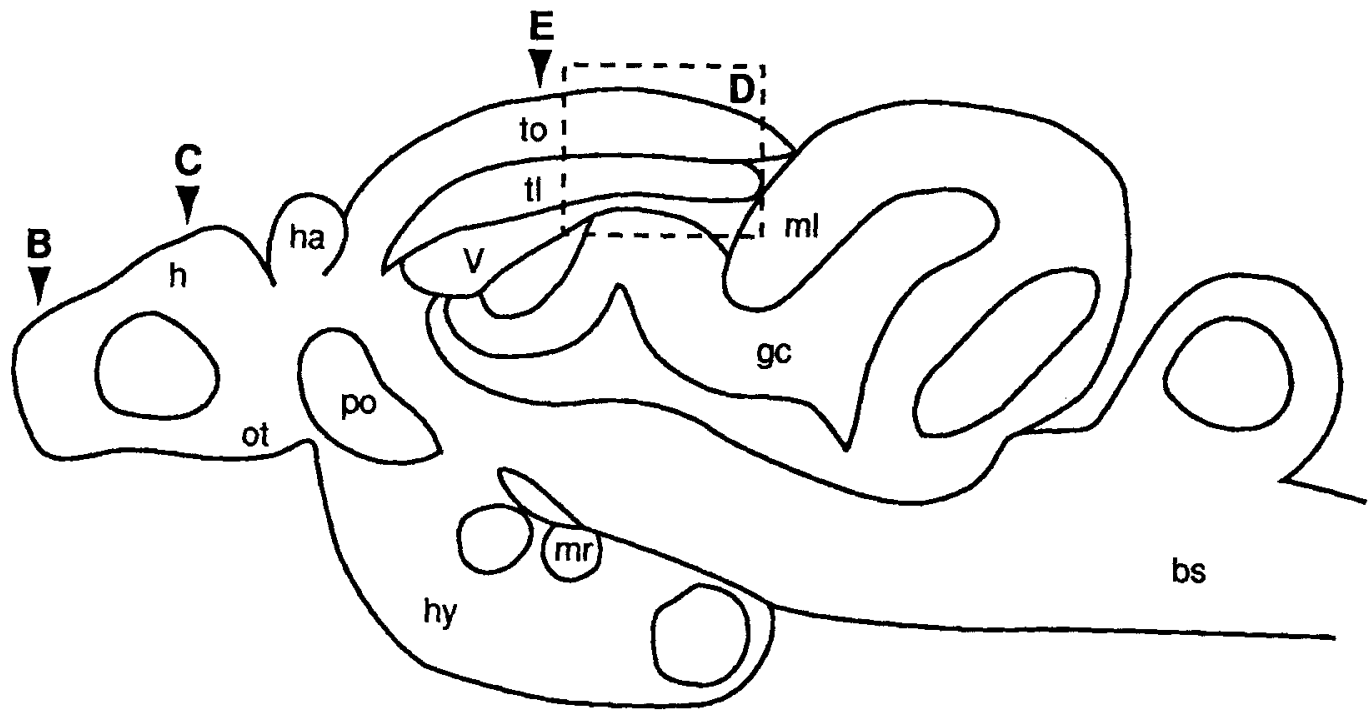

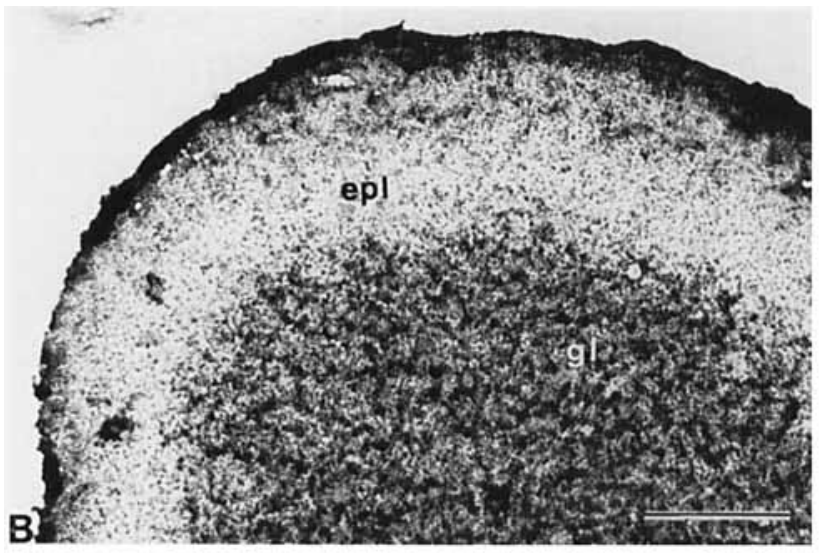

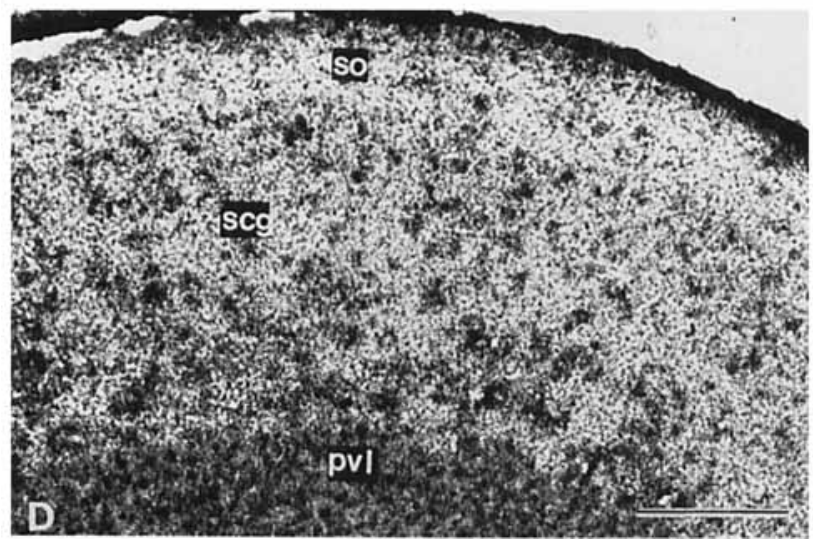

Fig. 3. Localization of TSP in the goldfish brain. A: Diagram of a sagittal section of a goldfish brain (after Romer and Parsons, 1977). The dashed box indicates the region corresponding to photomicrograph $\mathrm{E}$ and arrowheads indicate the level of coronal sections. B: In the olfactory bulb, immunostaining was present in the granule cell layer (gl), but not the external plexiform layer (epl). C: Intense reaction product was present throughout the hippocampus $(h)$. D: In the optic
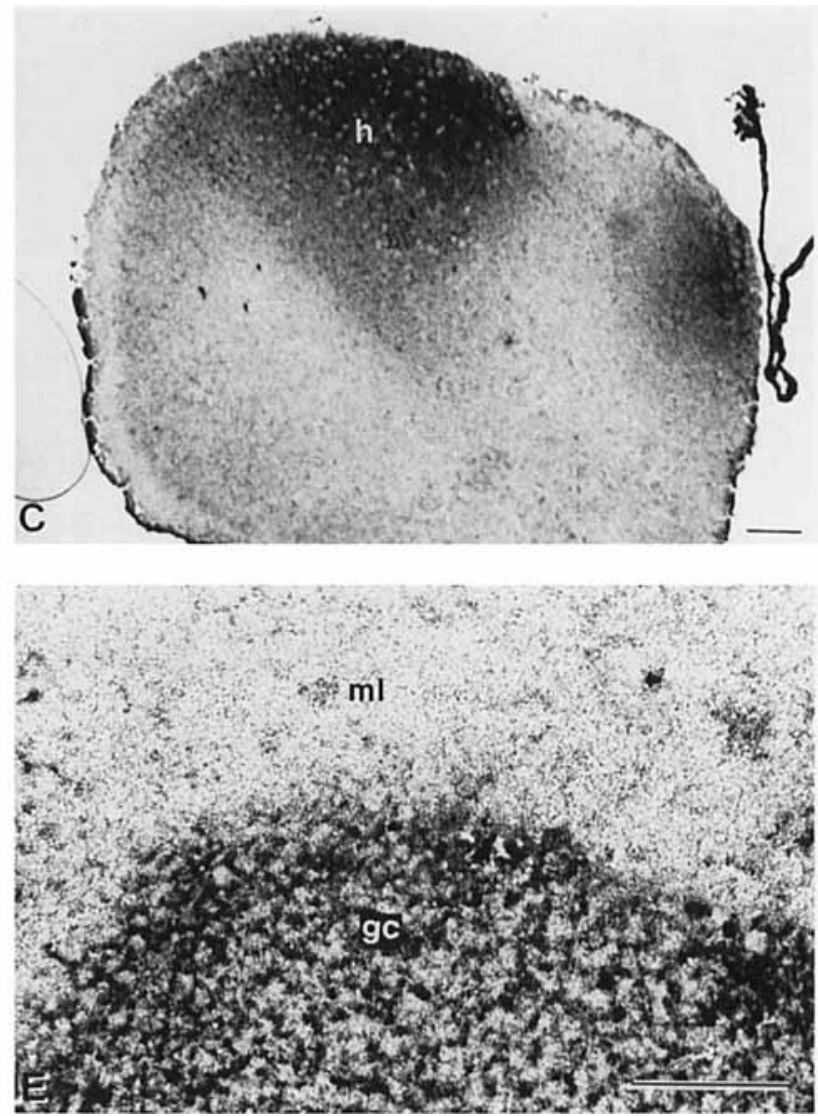

tectum, there was intense immunoreactivity in the periventricular layer (pvI), and staining was also present in the stratum centrale griseum (scg) but not in the stratum opticum (so). E: TSP immunoreactivity was found primarily in the granule cell layer (gc) of the goldfish cerebellum, with little in the molecular layer $(\mathrm{ml})$. The secondary antibody was a strepavigen-alkaline phosphatase conjugate. Scale bars $=100 \mu \mathrm{m}$. 


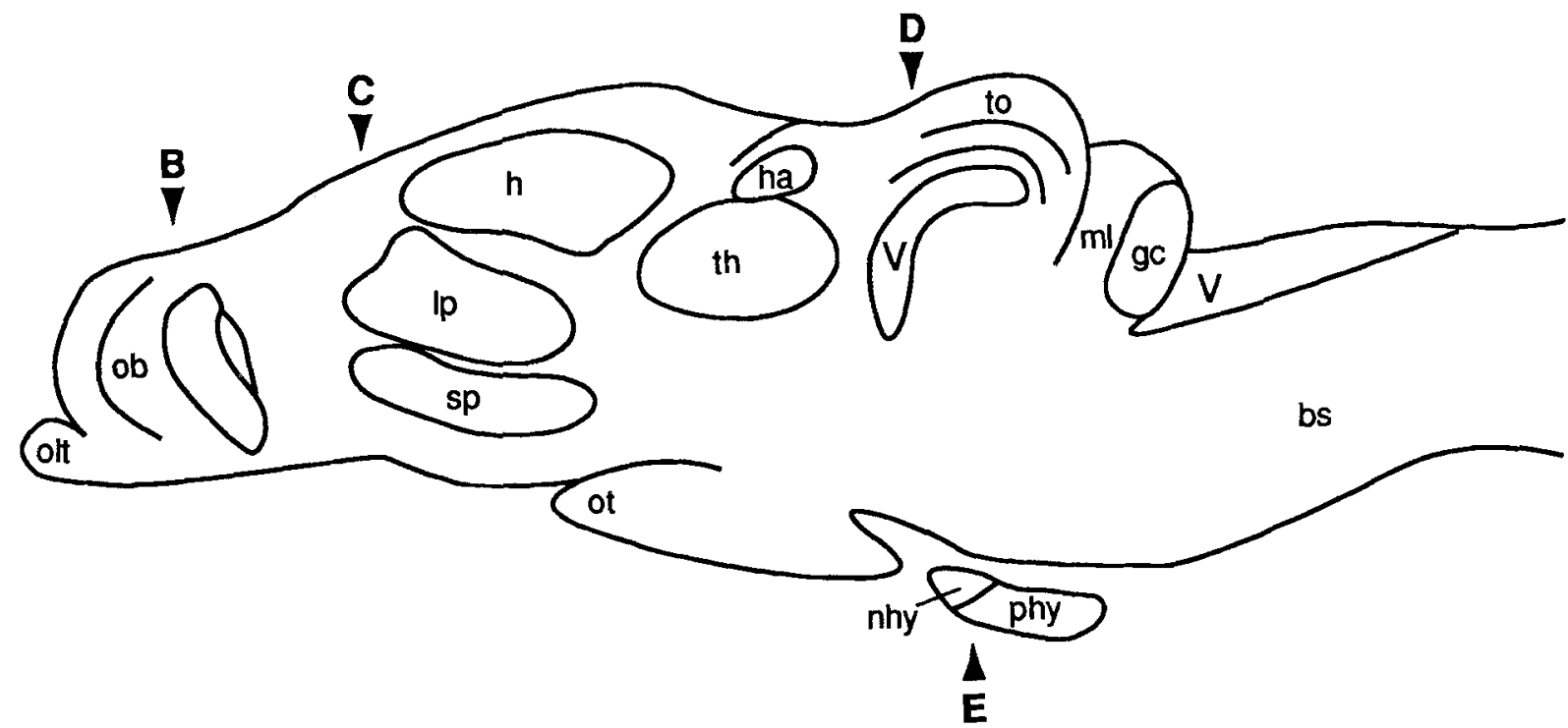

A
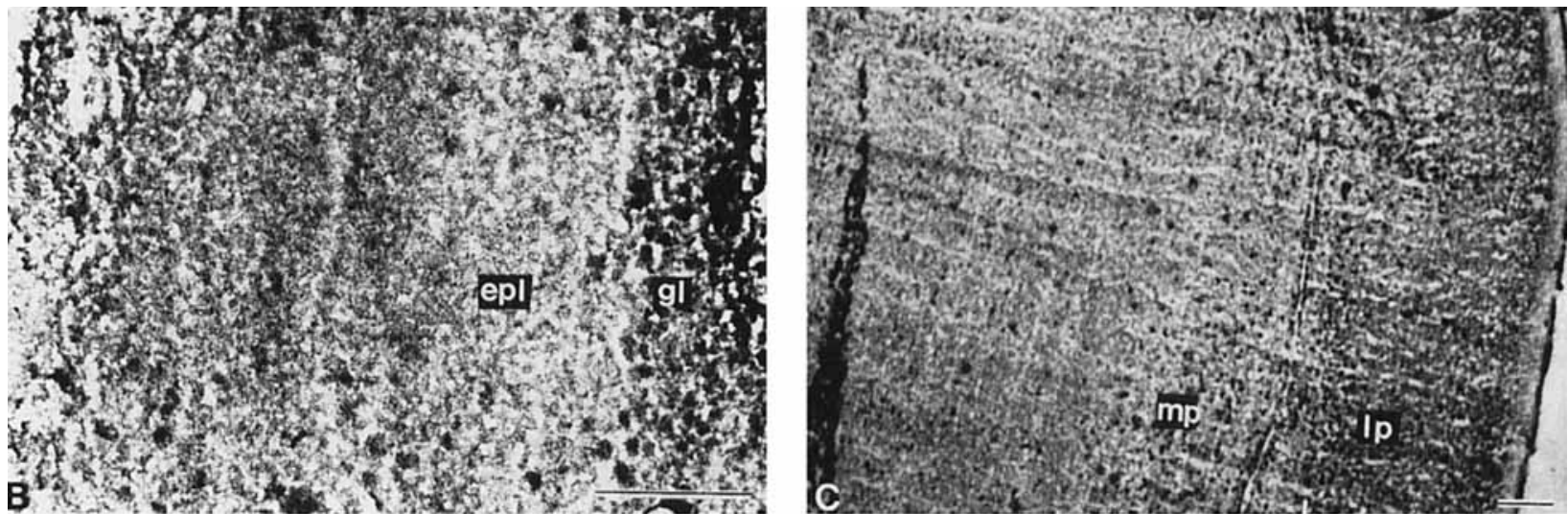

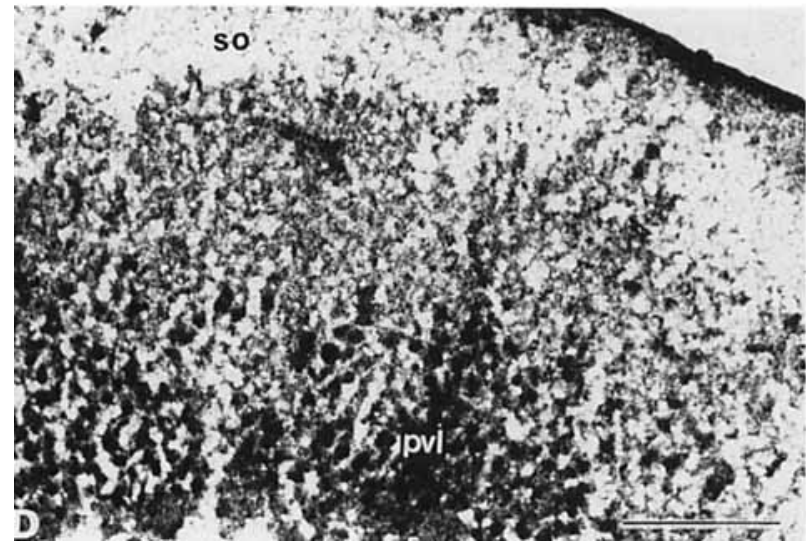

Fig. 4. TSP localization in the Xenopus brain. A: Diagram of a sagittal section of adult Xenopus brain (after Kemali and Braitenberg, 1971); arrowheads indicate the level of coronal sections in the photomicrographs below. B: In the olfactory lobe, immunoreaction product was found in the granule cell (gl) and external plexiform layers (epl). C: TSP was present in the medial pallium (mp), and more intensely in the

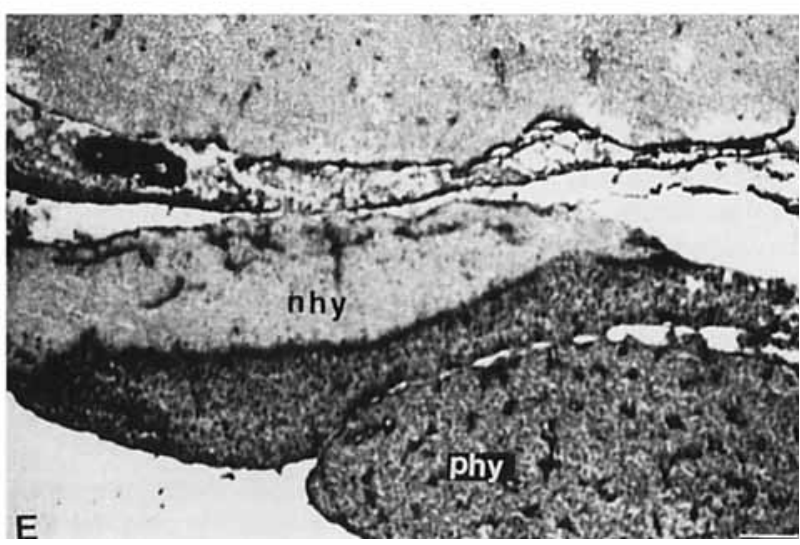

lateral pallium (lp). D: It was also present in the periventricular layer (pvl), but not the stratum opticum (so) of the optic tectum. E: TSP was densely deposited in the primary lobe of the hypophysis (phy), but not in the neural lobe of the hypophysis (nhy). The secondary antibody was conjugated to strepavigen-alkaline phosphatase. V, ventricle. Scale bars $=100 \mu \mathrm{m}$. 
TABLE 1. Survey Results of Levels of TSP Immunoreactivity in Various Brain Regions ${ }^{1}$

\begin{tabular}{|c|c|c|c|c|c|c|c|c|}
\hline \multirow[b]{2}{*}{ Region } & \multicolumn{2}{|c|}{ Mouse } & \multicolumn{2}{|c|}{ Goldfish } & \multicolumn{2}{|c|}{ Frog } & \multicolumn{2}{|c|}{ Newt } \\
\hline & Neuropil & Cells & Neuropil & Cells & Neuropil & Cells & Neuropil & Cells \\
\hline External plexifrom layer & ++ & & $+1-$ & & + & + & + & \\
\hline Mitral cell layer & ++ & $+1-$ & + & - & ++ & $+1-$ & $+t$ & $+1-$ \\
\hline Granule cell layer & + & $+1-$ & ++ & - & ++ & $+1-$ & $+t$ & $+1-$ \\
\hline Medial pallium/hippocampus & $-\sim^{2}$ & & +++ & $+1-$ & ++ & ++ & $+t$ & $+1-$ \\
\hline Lateral pallium & \multicolumn{2}{|c|}{$\mathrm{N} / \mathrm{A}$} & \multicolumn{2}{|c|}{$\mathrm{N} / \mathrm{A}$} & ++ & ++ & ++ & $+1-$ \\
\hline Subpallium/caudate putamen & - & ++ & \multirow{2}{*}{\multicolumn{2}{|c|}{$\mathrm{N} / \mathrm{A}$}} & ++ & $+1-$ & ++ & $+1-$ \\
\hline Thalamus & + & ++ & & & ++ & + & ++ & $+1-$ \\
\hline Habenula & + & ++ & $+t$ & +++ & ++ & + & + & - \\
\hline Hypothalamus & - & ++ & + & ++ & + & & ++ & $+1-$ \\
\hline Mammillary region & $+1-$ & & $+t$ & $t+$ & \multicolumn{2}{|c|}{$\mathrm{N} / \mathrm{A}$} & \multicolumn{2}{|c|}{$\mathrm{N} / \mathrm{A}$} \\
\hline Preoptic nucleus & \multicolumn{2}{|c|}{$\mathrm{N} / \mathrm{A}$} & ++ & ++ & ++ & ++ & ++ & $+1-$ \\
\hline Optic tectum/inferior and superior collicus & + & ++ & ++ & ++ & ++ & + & + & $+1-$ \\
\hline Molecular layer of cerebellum & + & + & ++ & & ++ & & + & \\
\hline Granule layer of cerebellum & $+1-$ & & ++ & $+1-$ & $++t$ & $+1-$ & ++ & $+1-$ \\
\hline
\end{tabular}

$1_{-},+1-,+,+++++$ represent increasing levels of chromagen deposition. $N / A$ indicates regions not present or not identified.

${ }^{2}$ Results of mouse hippocampus: dentate molecular layer, - ; hilus of dentate gyrus, + ; granular layer, +++ .

within the adult Xenopus sciatic nerve, in the endoneurium as well as the epineurium (Fig. 8G). In the newt sciatic nerve, TSP was present in the epineurium and endoneurium. TSP staining was observed within the axons, but its appearance was coarser than in the mouse sciatic nerve (Fig. 8H).

\section{DISCUSSION}

Thrombospondin is an extracellular matrix molecule that has been implicated in a wide range of neuronal cell migrations and in neurite outgrowth during development (O'Shea and Dixit, '88; Boyne et al., '89, '90, in preparation; O'Shea et al., '90), that supports neurite outgrowth in vitro (Neugebauer et al., '91; O'Shea et al., '91; Osterhout et al., '92), its expression correlating strongly with adult nerve regeneration in vivo (Hoffman et al., '90, '91, in preparation). TSP expression dramatically decreases at end stages of CNS development (O'Shea and Dixit, '88). 'TSP immunoreactivity was present in systems capable of regeneration in the adult: goldfish and newt spinal cords; goldfish, Xenopus, and newt optic nerves; and mouse, Xenopus, and newt sciatic nerves. TSP immunoreactivity was absent from the neuropil of the mouse and Xenopus spinal cords and from the mouse optic nerve. Although TSP immunoreactivity was associated with neurons in all species examined, the presence of TSP in the neuropil or extracellular matrix is strongly correlated with the regenerative potential of adult nervous systems.

It was originally thought that the CNS lacked an ECM (review by Rutka et al., '88); however, a variety of ECM components [heparan sulfate (Klinger et al., '85) and chondroitin sulfate (Bertolotto et al., '90; Flaccus et al., '91; Bignami et al., '92b; Iwata and Carlson, '93) proteoglycans, hyaluronate (Asher et al., '91; Bignami et al., '92a,b), and neuronectin (Rettig et al., '88; Garin-Chesa et al., '89)] are now known to be present within the CNS. Adhesive glycoproteins associated with neuronal migration and neurite outgrowth such as fibronectin (Thiery et al., '82; LeDourain, '84; Boucaut et al., '84) and laminin (Rogers et al., '83; Liesi, '85a) appear to be restricted in the adult CNS to basement membranes present at the meninges and surrounding blood vessels (Liesi et al., '84; Rutka et al., '88). Certain molecules present in the adult CNS may inhibit neurite outgrowth (Carbonetto et al., '83; Manthorpe et al., '83; Aquino et al., '84; Snow et al., '90a,b; Steindler et al., '90; Schwab, '91), and the interaction of proteoglycans with other ECM molecules can cause molecules to become inhibitory to neurite outgrowth (Verna et al, '89; Snow et al., '90a) or to become more neurotrophic (Matthiessen et al., '89; Riopelle and Dow, '90; Muller et al., '91; JohnsonGreen et al., '92). Therefore, the inability of the adult central nervous system to support nerve regeneration may result from a bias toward the inhibitory, rather than the supportive molecules characteristic of the developing CNS ECM.

Complex interactions occur between cells and their environment during neural development (Werz and Schachner, '88; Probstmeier et al,, '89; Crossin et al., '90; Herndon and Lander, '90). These interactions are mediated by cell adhesion molecules, ECM molecules, and cell-surface receptors (Sanes, '89); with maturation, the prevalence of many of these molecules is decreased (Liesi et al., '84). The presence of these components, or alternatively, lack of inhibitory substances, may ultimately underly the observed ability of grafts of embryonic CNS (Tessler et al., '88), or of adult PNS (David and Aguayo, '81; Schwab and Thoenen, '85) to support regeneration, while grafts of adult CNS such as optic nerve (Politis and Spencer, '86) or spinal cord (Fernandez et al., '84) do not.

The presence of TSP in the neuropil of the mouse brain was somewhat unexpected, given that mammalian CNS neurons do not readily regenerate. However, CNS gray matter will support limited neurite outgrowth in vitro (Savio and Schwab, '90), similar to the abortive sprouting observed in response to trauma in vivo (Ramón y Cajal, '28). Interestingly, it was recently suggested that TSP may play a role in neuronal degeneration and plaque formation in Alzheimer's disease (Buee et al., '92). Localization studies have indicated that TSP was present in plaques, and was lost from a subset of pyramidal neurons in these brains.

There was a much greater correlation between the presence of TSP and regenerative potential in central nerve tracts and spinal cords than in cortical regions. The absence of TSP reactivity in mouse fiber tracts, in contrast to goldfish fiber tracts, was predicted for a molecule involved in regeneration, given the much greater capacity for nerve repair of the goldfish. High levels of TSP in the white matter of the spinal cords correlates with the species ability to support nerve regeneration (Windle, '56; Clemente, '64). In particular, the presence of TSP in the ependymal layer is interesting, as the regenerating ependymal tube may guide regenerating neurites following spinal cord trauma in newts (Anderson et al., '83). This correlation is reinforced by the dramatic decrease in levels of TSP in the frog spinal 


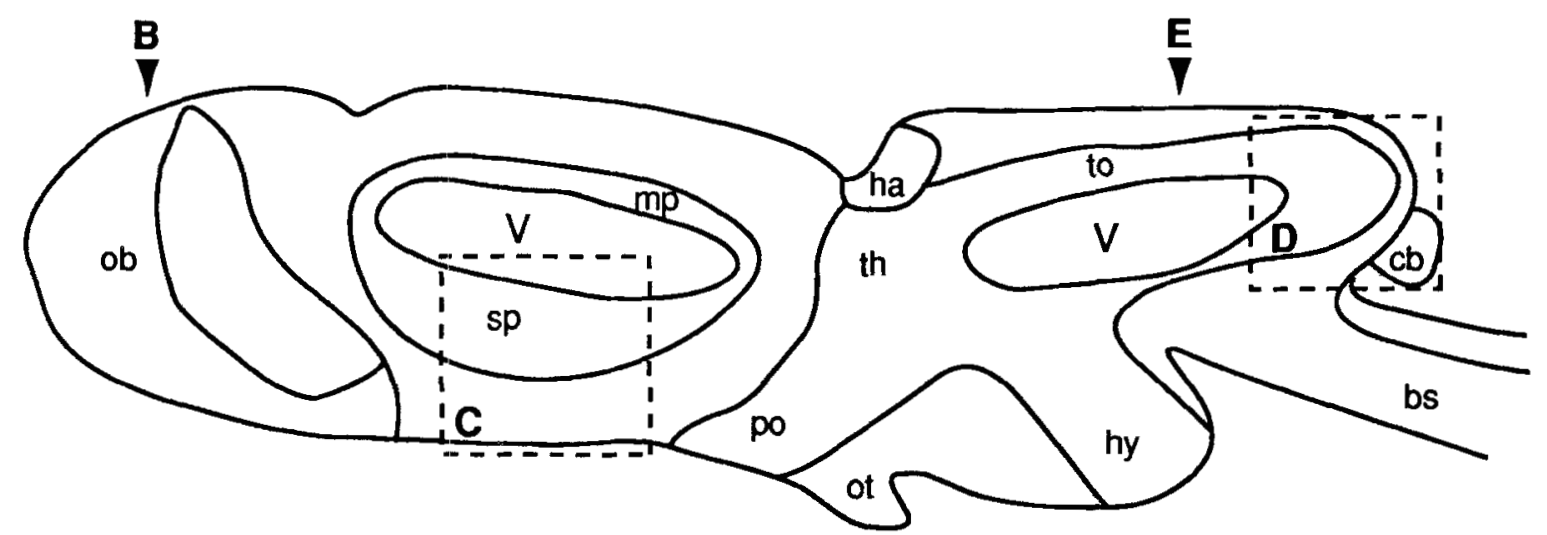

A
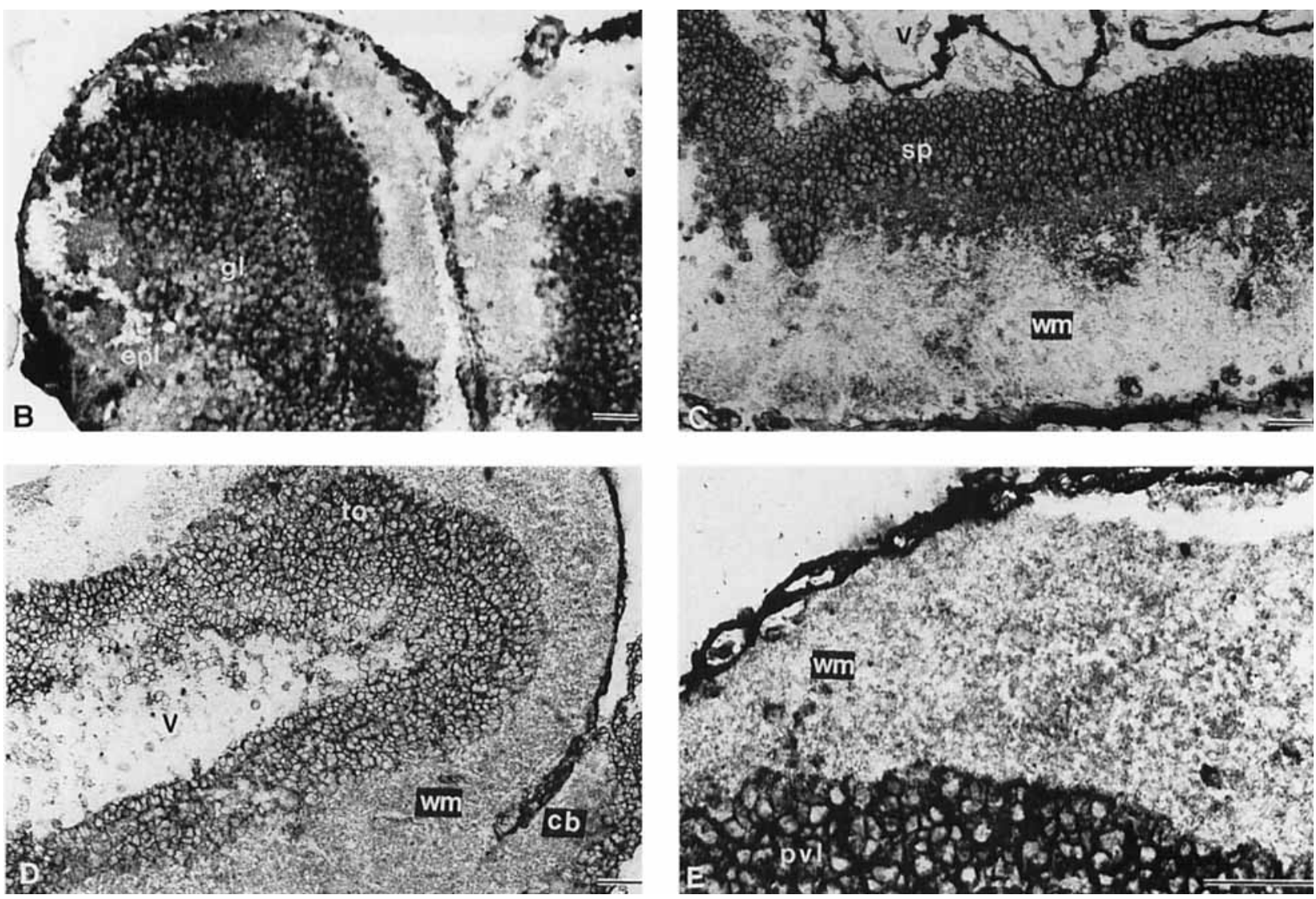

Fig. 5. Localization of TSP in the newt brain. A: Diagram of a sagittal section of a newt brain (after Herrick, 1948). Dashed boxes indicate corresponding photomicrographs below, and arrowheads indicate levels of coronal sections. B: In the olfactory lobe, immunoreaction product was densely deposited in the granule cell layer (gl), with diffuse staining of the external plexiform layer (epl). C: Anti-TSP reaction product was intense in the subpallium (sp), with less in the white

cord following metamorphosis, but persistence of TSP in the adult optic nerve, which retains the ability to regenerate.

It has long been accepted that neurite outgrowth is a contact-mediated process requiring an adhesive substrate

matter (wm). D: TSP was present in the optic tectum (to) and in the granule cell layer of the cerebellum (cb) and diffusely in the white matter (wm). E: In the optic tectum, immunoreactivity was prevalent in the periventricular layer (pvl), and was present at lower levels in the white matter (wm). V, ventricle. The secondary antibody was conjugated to strepavigen-alkaline phosphatase. Scale bars $=100 \mu \mathrm{m}$.

(Letourneau, '79). TSP supports neurite outgrowth in vitro (Neugebauer et al., '91; O'Shea et al., '91) and has several distinct domains involved in cell adhesion (Murphy-Ullrich and Mosher, '87; Roberts et al., '87; Lawler et al., '88; Prater et al., '91). Like other adhesive glycoproteins [such 

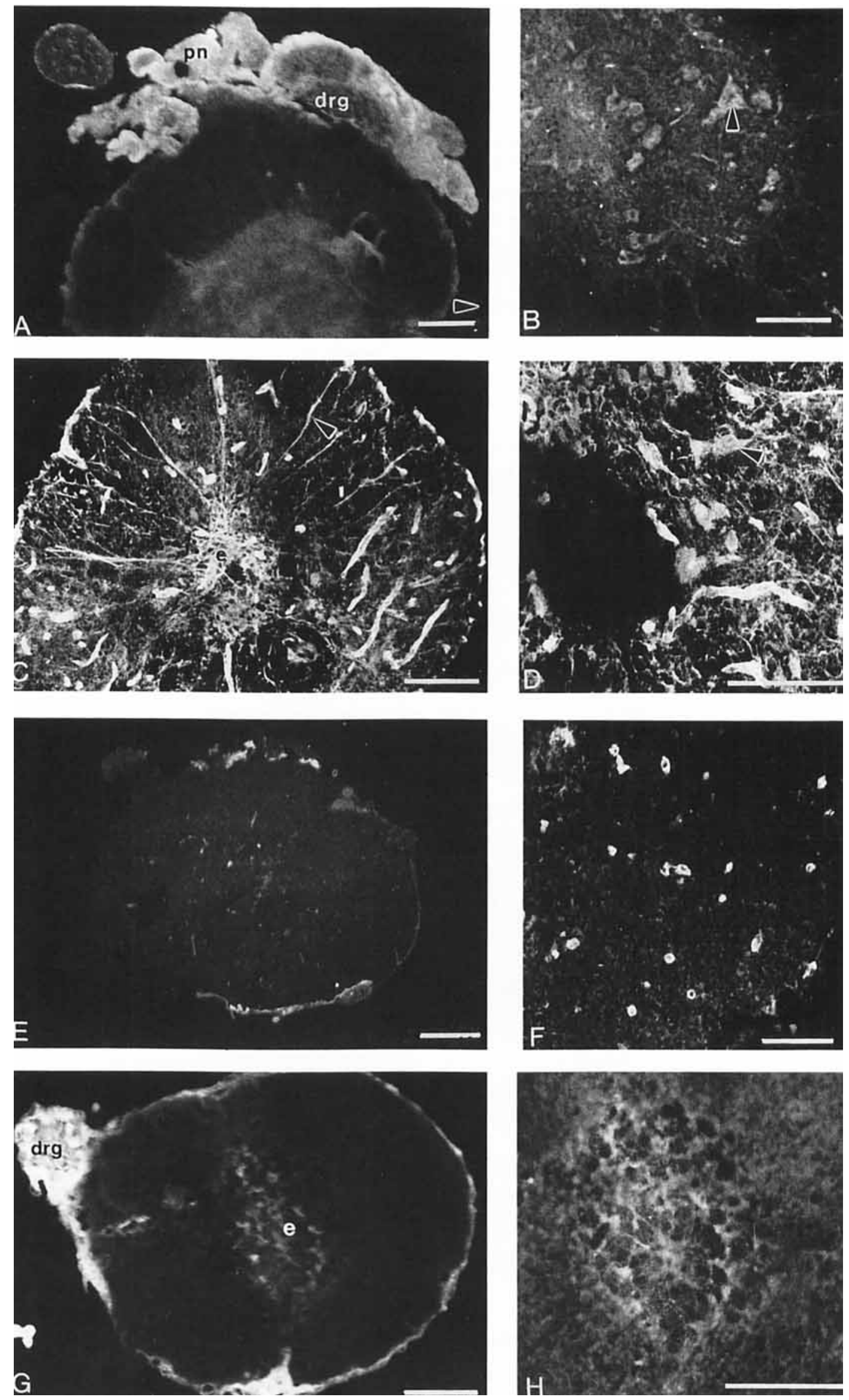

Figure 6 

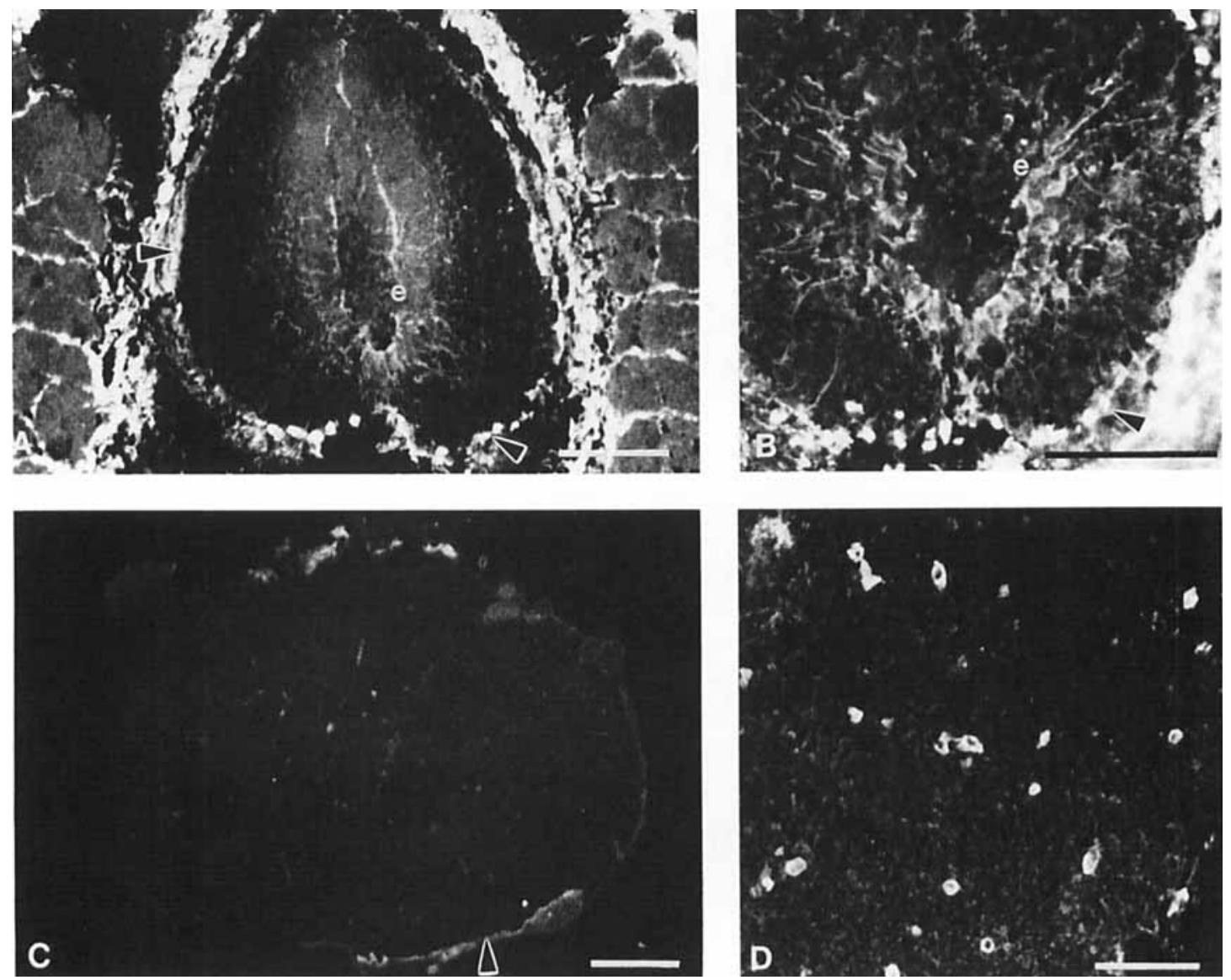

Fig. 7. Low (A,C) and higher magnification views of the spinal cord of juvenile (A,B) and adult $(\mathbf{C}, \mathbf{D})$ Xenopus. In the juvenile spinal cord, thrombospondin immunoreactivity was present throughout both the ependymal layer (e) and in glial fibers (A,B). TSP was virtually absent from the adult spinal cord (C) and was present only in isolated glial cell bodies (D), random neurons, and pia (arrowheads). The secondary antibody was conjugated to FITC. Scale bars $=100 \mu \mathrm{m}$ in A and D, 60 $\mu \mathrm{m}$ in $\mathrm{B}, 500 \mu \mathrm{m}$ in $\mathrm{C}$. as laminin (Kleinman et al., '85), fibronectin (Ruoslahti et al., '81), and tenascin (Erickson and Bourdon, '89)], TSP binds a variety of other ECM components. Thus, TSP may serve as a substrate or may function to organize other adhesive matrix components required for axonal regeneration.

In addition to the presence of a suitable substrate, neurite outgrowth is dependent upon controlled protease activity to allow passage of growth cones through the complex cell and matrix filled environment (Moonen et al., '82; Pittman et al., '89a,b; McGuire and Seeds, '90). Plasminogen activator is released by growth cones (Krystosek and Seeds, '84) and has been implicated in neurite outgrowth from sensory neurons (Krystosek and Seeds, '84; Pittman, '85; McGuire and Seeds, '90), sympathetic neu- rons (Pittman, '85; Pittman et al., '89a), PC12 cells (Pittman et al., '89a; Saito et al., '90), and neuroblastoma cells (Shea et al., '91). The plasmin activity generated by these activators appears to be required for neurite penetration and growth into a three-dimensional ECM (Pittman and Williams, '88). TSP is unique in that binding of protease nexin I (Browne et al., '88), plasminogen (Silverstein et al., '84), and tissue- and urokinase-type plasminogen activators (Silverstein et al., '86, '90) stimulates plasmin synthesis as much as 40 -fold (Silverstein and Nachman, '87). Careful regulation of protease activity is required for neurite extension, as too much activity results in an inhibition of neurite outgrowth (Hawkins and Seeds, '86, '89). TSP may therefore play a unique role in neurite outgrowth because of its ability to organize ECM molecules and growth factors and
Fig. 6. Thrombospondin localization in spinal cords using fluorscein isothiocyanate (FITC)-conjugated secondary antibodies. A: In a transverse section of mouse spinal cord, TSP immunoreactivity was intense in the dorsal root ganglion (drg) and associated peripheral nerve (pn; arrowhead indicates dorsal). B: Higher magnification of mouse spinal cord illustrating staining in cell bodies of motor neurons (arrowhead; dorsal is toward the top of the figure). C: In goldfish spinal cord, TSP was present in the ependymal layer (e), radial glia cells (arrowhead). D:
Higher magnification of goldfish spinal cord illustrating staining of motor neurons (arrowhead). Low (E) and higher magnification (F) views of the frog spinal cord illustrating the presence of TSP in scattered neurons and glial cells. G: In the newt spinal cord, TSP was present in dorsal root ganglia (drg), surrounding cells of the gray matter, and surrounding ependymal cells (e). H: Higher magnification of G illustrating the deposition of TSP on ependymal cell surfaces. Scale bars $=200$ $\mu \mathrm{m}$ in $\mathrm{A}, 100 \mu \mathrm{m}$ in $\mathrm{B}, \mathrm{C}, \mathrm{F}$, and $\mathrm{G}, 60 \mu \mathrm{m}$ in $\mathrm{D}, \mathrm{H}, 500 \mu \mathrm{m}$ in $\mathrm{E}$. 

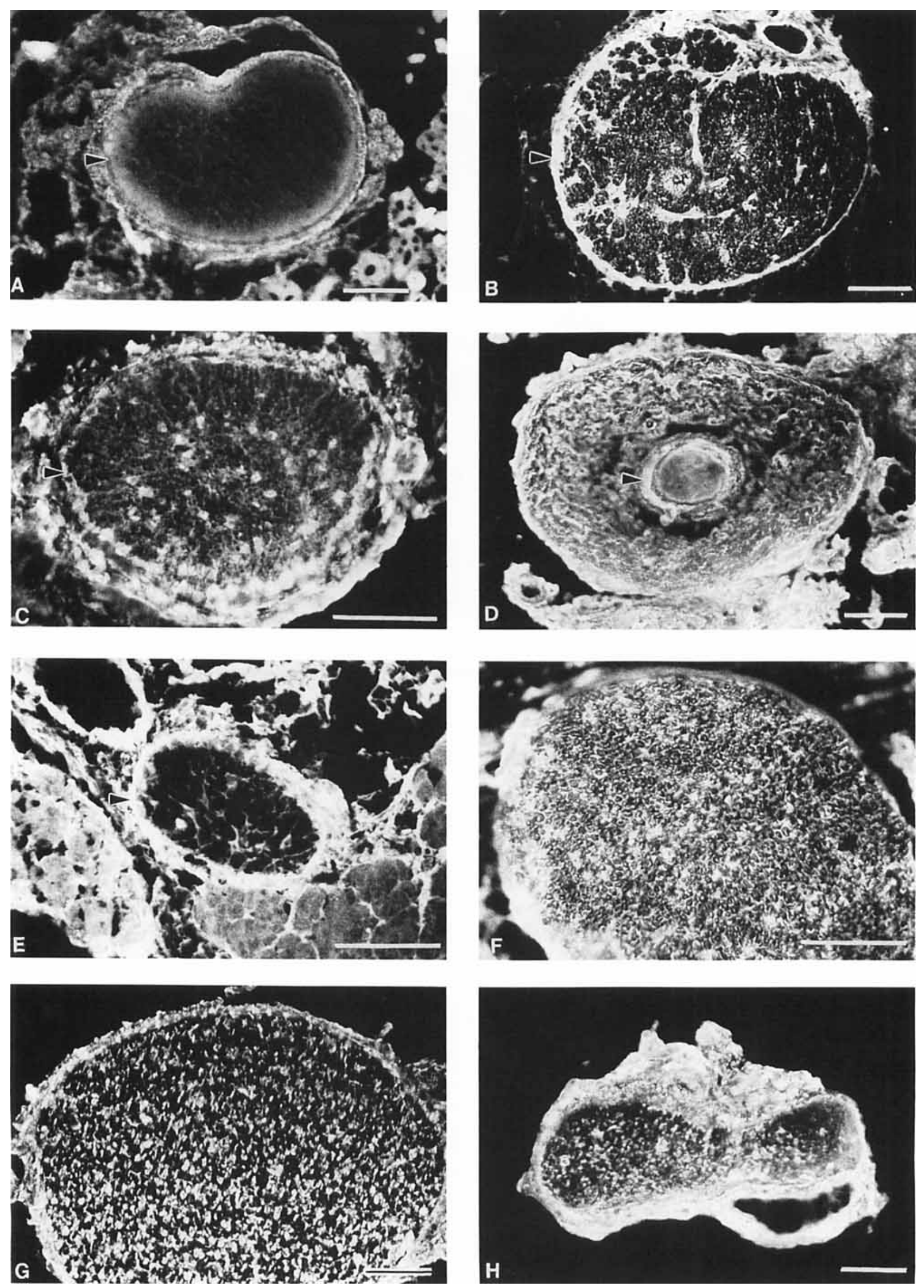
Fig. 8. Thrombospondin localization in optic and sciatic nerves. A: TSP was virtually absent from the mouse optic nerve, but was present in the connective tissue pia-arachnoid layer (arrowhead). It was present in glial cells, in the pia-arachnoid layer (arrowheads), and neuropil of the goldfish (B), adult Xenopus (C), newt (D), and juvenile Xenopus (E) optic nerves. TSP was present in the epineurium, perineurium, and axons of the mouse $(\mathbf{F})$, Xenopus $(\mathbf{G})$, and newt $(\mathbf{H})$ sciatic nerves. Scale bars $=100 \mu \mathrm{m}$.

to provide an adhesive substrate for cells and their processes, as well as to provide a mechanism for focusing localized proteolysis of that substrate.

This work demonstrates that TSP is expressed at higher levels in CNS regions capable of regeneration following trauma. Previous work has shown that TSP expression is associated with neuronal migration and neurite elongation during development (O'Shea and Dixit, '88; O'Shea et al., '90), and that TSP supports neurite outgrowth in vitro (Neugebauer et al., '91; O'Shea et al., '91; Osterhout et al., '92). Lesion studies of mouse sciatic (Hoffman et al., '90) and mouse optic and goldfish optic nerves (Hoffman et al, '91) support a correlation between the presence of TSP and successful nerve regeneration. While it is unlikely that TSP alone is responsible for determining the success or failure of regeneration, its localization in systems capable of regeneration suggests that TSP plays an important role in nerve regeneration.

\section{ACKNOWLEDGMENTS}

The authors are grateful to Drs. P. Raymond and S. Easter for help in the brain region identifications, Dr. M. Murray for useful discussion, and K.M. O'Rourke for excellent technical assistance. This work was supported by a grant from the American Paralysis Association (to K.S.O.), an NIH grant HD 23687 (to K.S.O.), a Developmental Biology Training grant HD-07274 (to J.R.H.), and a University of Michigan Rackham Dissertation grant (to J.R.H.).

\section{LITERATURE CITED}

Anderson, M.J., S.G. Waxman, and M. Laufer (1983) Fine structure of regenerated ependyma and spinal cord in Sternarchus albifrons. Anat. Rec. 205:73-83.

Aquino, D.A., R.U. Margolis, and R.K. Margolis (1984) Immunocytochemical localization of a chrondroitin sulfate proteoglycan in nervous tissue. I. Adult brain, retina, and peripheral nerve. J. Cell Biol. 99:1117-1129.

Asher, R., G. Perides, J.-J. Vanderhaeghen, and A. Bignami (1991) Extracellular matrix of central nervous system white matter: Demonstration of a hyaluronate-protein complex. J. Neurosici. Res. 28:410-421.

Baenzinger, N.L., G.N. Brodie, and P.W. Majerus (1971) A thrombinsensitive protein of human platelet membranes. Proc. Natl. Acad. Sei. USA $68: 240-243$.

Bertolotto, A., G. Rocca, and D. Schiffer (1990) Chondroitin 4-sulfate proteoglycan forms an extracellular network in human and rat central nervous system. J. Neurol. Sci. 100:113-123.

Bignami, A., G. Perides, R. Asher, and D. Dahl (1992a) The astrocyteextracellular matrix complex in CNS myelinated tracts: A comparative study on the distribution of hyaluronate in rat, goldfish and lamprey. J. Neurocytol. 21:604-613.

Bignami, A., R. Asher, and G. Perides (1992b) The extracellular matrix of rat spinal cord: A comparative study on the localization of hyaluronic acid, glial hyaluronate-binding protein, and chondrotin sulfate proteoglycan. Exp. Neurol. 117:90-93.

Bohn, R.C., P.J. Reier, and E.B. Sourbeer (1982) Axonal interactions with connective tissue and glial substrata during optic nerve regeneration in Xenopus larvae and adults. Am. J. Anat. 165:397-419.
Boucaut, J.-C., T. Darribere, T.J. Poole, H. Aoyama, K.M. Yamada, and J.-P. Thiery (1984) Biologically active synthetic peptides as probes of embryonic development: A competitive peptide inhibitor of fibronectin function inhibits gastrulation in amphibian embryos and neural crest cell migration in avian embryos. J. Cell Biol. 99:1822-1830.

Boyne, L.J., K.S. O'Shea, and V.M. Dixit (1989) Neural crest migration on an extracellular matrix protein thrombospondin. J. Cell Biol. 109:112a (abstract).

Boyne, L.J., K.S. O'Shea, and V.M. Dixit (1990) Neural crest cells utilize thrombospondin as a migratory substratum in situ. Soc. Neurosci. Abstr. 16:312 (abstract).

Browne, P.C., J.J. Miller, and T.C. Detwiller (1988) Kinetics of the formation of thrombin-thrombospondin complexes: Involvement of a $77-\mathrm{kDa}$ intermediate. Arch. Biochem. Biophys. 265:534-538.

Buee, L., P.R. Hoff, D.D. Roberts, A. Delacourte, J.H. Morrison, and H.M. Fillit (1992) Immunohistochemical identification of thrombospondin in normal human brain and in Alzheimer's disease. Am. J. Pathol. 141:783788.

Carbonetto, S., M.H. Gruver, and D. Turner (1983) Nerve fiber growth in culture on fibronectin, collagen, and glycosaminoglycan substrates. J. Neurosci. 3:2324-2335.

Clemente, C.D. (1964) Regeneration in the vertebrate central nervous system. Rev. Neurobiol. 6:267-301.

Crossin, K.L., A.L. Prieto, S. Hoffman, F.S. Jones, and D.R. Friedlander (1990) Expression of adhesion molecules and the establishment of boundaries during embryonic and neural development. Exp. Neurol. 109:6-18.

David, S., and A.J. Aguayo (1981) Axonal elongation into peripheral nervous system 'bridges' after central nervous system injury in adult rats. Science 214:931-933.

Dixit, V.M., G.A. Grant, S.A. Santoro, and W.A. Frazier (1984) Isolation and characterization of a heparin-binding domain from the amino terminus of platelet thrombospondin. J. Biol. Chem. 259:10100-10105.

Easter, S.S., J.T. Schmidt, and S.M. Leber (1978) The paths and destinations of the induced ipsilateral retinal projection in goldfish. J. Embryol. Exp. Morphol. 45:145-159.

Erickson, H.P., and M.A. Bourdon (1989) Tensacin: An extracellular matrix protein prominent in specialized embryonic tissues and tumors. Annu. Rev. Cell Biol. 5:71-92.

Fernandez, E., R. Pallini, G. Maira, and A. Mangiola (1984) Peripheral nerve autografts to the spinal cord in rats. Brain Res. 372:198-203.

Flaccus, A., A. Janetzko, H. Tekotte, R.K. Margolis, and R.U. Margolis (1991) Immunocytochemical localization of chondroitin and chodroitin 4- and 6-sulfates in developing rat cerebellum. J. Neurochem. 56:16081615 .

Garin-Chesa, P., M.R. Melamed, and W.J. Rettig (1989) Immunohistochemical analysis of human neuronectin expression in normal, reactive, and neoplastic tissues. J. Histochem. Cytochem. 37:1767-1776.

Hawkins, R.L., and N.W. Seeds (1986) Effects of proteases and their inhibitors on neurite outgrowth from neonatal mouse sensory ganglia in culture. Brain Res. 389:63-70.

Hawkins, R.L., and N.W. Seeds (1989) Protease inhibitors influence the direction of neurite outgrowth. Dev. Brain Res. 45:203-209.

Herndon, M.E., and A.D. Lander (1990) A diverse set of developmentally regulated proteoglycans is expressed in the rat central nervous system. Neuron 4:949-961.

Herrick, C.J. (1948) The Brain of the Tiger Salamander, Ambystoma tigrinum. Chicago: University of Chicago Press.

Hoffman, J.R., K.S. O'Shea, and V.M. Dixit (1990) Localization of thrombospondin in mouse sciatic nerve following nerve crush or transection. Soc. Neurosci. Abstr. 16:338 (abstract).

Hoffman, J.R., K.S. O'Shea, and V.M. Dixit (1991) Localization of thrombospondin following optic nerve crush in the mouse and goldfish. Soc. Neurosei. Abstr. 17:48 (abstract).

Iwata, M., and S.S. Carlson (1993) A large chondroitin sulfate proteoglycan has the characteristics of a general extracellular matrix component of adult brain. J. Neurosci. 13:195-207.

Johnson-Green, P.C., K.E. Dow, and R.J. Riopelle (1992) Neurite growth modulation associated with astrocyte proteoglycans: Influence of activators of inflammation. Glia $5: 33-42$.

Kemali, M., and V. Braitenberg (1969) Atlas of the Frog's Brain. Berlin: Springer-Verlag.

King, G.M., and D.R.N. Custance (1982) Colour Atlas of Vertebrate Anatomy, an Integrated Text and Dissection Guide. Oxford: Blackwell Scientific Publications. 
Kleinman, H.K., F.B. Cannon, G.W. Laurie, J.R. Hassell, M. Aumailley, V.P. Terranova, G.R. Martin, and M. DuBois-Dalcq (1985) Biological activities of laminin. J. Cell. Biochem. 27:317-325.

Klinger, M.M., R.U. Margolis, and R.K. Margolis (1985) Isolation and characterization of the heparan sulfate proteoglycans of brain. Use of affinity chromatography on lipoprotein lipase-agarose. J. Biol. Chem. 260:4082-4090.

Krystosek, A., and N.W. Seeds (1984) Peripheral neurons and Schwann cells secrete plaminogen activator. J. Cell Biol. 98:773-776.

Lahav, J., J. Lawler, and M.A. Gimbrone (1984) Thrombospondin interactions with fibronectin and fibrinogen: Mutual inhibition in binding. Eur. J. Biochem. 145:151-156.

Lahav, J., M.A. Schwartz, and R.O. Hynes (1982) Analysis of platelet adhesion with a radioactive chemical crosslinking reagent. Interaction of thrombospondin with fibronectin and collagen. Cell 31:253-262.

Laherty, C.D., K. O'Rourke, F.W. Wolf, R. Katz, M.F. Seldin, and V.M. Dixit (1992) Characterization of mouse thrombospondin 2 sequence and expression during cell growth and development. J. Biol. Chem. 267:32743281.

Lawler, J., and R.O. Hynes (1986) The structure of human thrombospondin, an adhesive glycoprotein with multiple calcium binding sites and homologies with several different proteins. J. Cell Biol. 103:1635-1648.

Lawler, J., L.H. Derick, J.E. Connolly, J.-H. Chen, and F.C. Chao (1985) The structure of human platelet thrombospondin. J. Biol. Chem. 260:37623772.

Lawler, J, R. Weinstein, and R.O. Hynes (1988) Cell attachment to thrombospondin: The role of ARG-GLY-ASP, calcium, and integrin receptors. J. Cell Biol. 107:2351-2361.

Lawler, J., M. Duquette, and P. Ferro (1991) Cloning and sequencing of chicken thrombospondin. J. Biol. Chem. 266:8039-8043.

LeDourain, N.M. (1984) Cell migrations in embryos. Cell 38:353-360.

Letourneau, P.C. (1979) Cell-substratum adhesion of neurite growth cones, and its role in neurite elongation. Exp. Cell Res. 124:127-138.

Liesi, P. (1985a) Laminin-immunoreactive glia distinguish regenerative adult CNS systems from non-regenerative ones. EMBO J. 4:2505-2511.

Liesi, P. (1985b) Do neurons in the vertebrate CNS migrate on laminin? EMBO J. 4:1163-1170.

Liesi, P., S. Kaakkola, D. Dahl, and A. Vaheri (1984) Laminin is induced in astrocytes of adult brain by injury. EMBO J. 3:683-686.

Majack, R.A., S.C. Cook, and P. Bornstein (1986) Control of smooth muscle cell growth by components of the extracellular matrix: Autocrine role for thrombospondin. Proc. Natl. Acad. Sci. USA 83:9050-9054.

Manthorpe, M., E. Engvall, E. Ruosiahti, F. Longo, G. Davis, and S. Varon (1983) Laminin promotes neuritic regeneration from cultured peripheral and central neurons. J. Cell Biol. 97:1882-1890.

Matthiessen, H.P., C. Schmalenbach, and H.W. Muller (1989) Astrogliareleased neurite growth-inducing activity for embryonic hippocampal neurons is associated with laminin bound in a sulfated complex and free fibronectin. Glia $2: 177-188$.

McGuire, P.G., and N.W. Seeds (1990) Degradation of underlying extracellular matrix by sensory neurons during neurite outgrowth. Neuron 4:633-642.

Moonen, G., M.P. Grau-Wagemans, and I. Selak (1982) Plasminogen activator-plasmin system and neuronal migration. Nature 298:753-755.

Muller, H.W., H.P. Matthiessen, C. Schmalenbach, and W.O. Schroeder (1991) Glial support of CNS neuronal survival, neurite growth and regeneration. Rest. Neurol. Neurosei. 2:229-232.

Mumby, S.M., G.J. Raugi, and P. Bornstein (1984) Interactions of thrombospondin with endothelial cells: Receptor-mediated binding and degradation. J. Cell Biol. 98:646-652.

Murphy-Ullrich, J.E., and D.F. Mosher (1987) Interactions of thrombospondin with endothelial cells: Receptor-mediated binding and degradation. J. Cell Biol. 105:1603-1611.

Neugebauer, K.M., C.J. Emmett, K.A. Venstrom, and L.F. Reichardt (1991) Vitronectin and thrombospondin promote retinal neurite outgrowth: Developmental regulation and role of integrins. Neuron 6:345-358.

Opdam, P., M. Kemali, and R. Nieuwenhuys (1976) Topological analysis of the brain stem of the frogs Rana esculenta and Rana catesbeiana. J. Comp. Neurol. 165:307-332.

O'Shea, K.S., and V.M. Dixit (1988) Unique distribution of the extracellular matrix component thrombospondin in the developing mouse embryo. $\mathbf{J}$. Cell Biol. 107:2737-2748.

O'Shea, K.S., J.S.T. Rheinheimer, and V.M. Dixit (1990) Deposition and role of thrombospondin in the histogenesis of the cerebellar cortex. J. Cell Biol. 110:1275-1283.
O'Shea, K.S., L.-H.J. Liu, and V.M. Dixit (1991) Thrombospondin and a 140 $\mathrm{kD}$ fragment promote adhesion and neurite outgrowth from embryonic central and peripheral neurons and from PC12 cells. Neuron 7:231-237.

Osterhout, D.J., W.A. Frazier, and D. Higgins (1992) Thrombospondin promotes process outgrowth in neurons from the peripheral and central nervous systems. Dev. Biol. 150:256-265.

Peter, R.E., and V.E. Gill (1975) A stereotaxic atlas and technique for forebrain nuclei of the goldfish, Carassius auratus. J. Comp. Neurol. 159:69-101.

Pittman, R.N. (1985) Release of plasminogen activator and a calciumdependent metalloprotease from cultured sympathetic and sensory neurons. Dev. Biol. 110:91-101.

Pittman, R.N., and A.G. Williams (1988) Neurite penetration into collagen gels requires $\mathrm{Ca}^{2+}$-dependent metalloproteinase activity. Dev. Neurosci. 11:41-51.

Pittman, R.N., J.K. Ivins, and H.M. Buettner (1989a) Neuronal plasminogen activators: Cell surface binding sites and involvement in neurite outgrowth. J. Neurosci. 9:4269-4286.

Pittman, R.N., P. Vos, J.K. Ivins, H.M. Buettner, and A. Repka (1989b) Proteases and inhibitors in the developing nervous system. In L.T. Landmesser (ed): The Assembly of the Nervous System. New York: Alan R. Liss.

Politis, M.J., and P.S. Spencer (1986) Regeneration of rat optic axons into peripheral nerve grafts. Exp. Neurol. 91:109-128.

Prater, C.A., J. Plotkin, D. Jaye, and W.A. Frazier (1991) The properdin-like type I repeats of thrombospondin contain a cell attachment site. J. Cell Biol. 112:1031-1040

Probstmeier, R., K. Kuhn, and M. Schachner (1989) Binding properties of the neural cell adhesion molecule to different components of the extracellular matrix. J. Neurochem. 53:1794-1801.

Ramón y Cajal, S. (1928) Degeneration and Regeneration of the Nervous System. R.M. May, trans. J. DeFelipe and E.G. Jones (eds), 1991. Oxford: Oxford University Press.

Reier, P.J., and J.D. Houle (1988) The glial scar: Its bearing on axonal elongation and transplantation approaches to CNS repair. Adv. Neurol 47:87-138

Rettig, W.J., P.G. Chesa, H.R. Beresford, M.R. Melamed, and L.J. Old (1988) Definition of an extracellular matrix protein in rostral portions of the human central nervous system. Brain Res. 438:315-322.

Riopelle, R.J., and K.E. Dow (1990) Functional interactions of neuronal heparan sulphate proteoglycans with laminin. Brain Res. 525:92-100.

Roberts, D.D., J.A. Sherwood, and V. Ginsburg (1987) Platelet thrombospondin mediates attachment and spreading of human melanoma cells. J. Cell Biol. 104: 131-139.

Rogers, S.L., P.C. Letourneau, S.L. Palm, J. McCarthy, and L.T. Furcht (1983) Neurite extension by peripheral and central nervous system neurons in response to substratum-bound fibronectin and laminin. Dev. Biol. 398:212-220.

Romer, A.S., and T.S. Parsons (1977) The Vertebrate Body, 5th ed. Philadelphia: Saunders College.

Roth, G. (1987) Visual behaviors in salamanders. In V. Braitenberg (ed) Studies of Brain Function, Vol. 14. Berlin: Springer-Verlag.

Ruoslahti, E., E. Engvall, and E.G. Hayman (1981) Fibronectin: Current concepts of its structure and functions. Coll. Res. 1:95-128.

Rutka, J.T., G. Apodaca, R. Stern, and M. Rosenblum (1988) The extracellular matrix of the central and peripheral nervous systems: Structure and function. J. Neurosurg. 69:155-170.

Saito, Y., S. Tsubuki, H. Ito, and S. Kawashima (1990) Possible involvement of a novel protease in neurite outgrowth of PC12 cells. Neurosci. Res. Suppl. 13:S97-S101.

Sanes, J.R. (1989) Extracellular matrix molecules that influence neural development. Annu. Rev. Neurosci. 12:491-516.

Sarnat, H.B., and M.T. Netsky (1981) Evolution of the Nervous System, 2nd ed. New York: Oxford University Press.

Savio, T., and M.E. Schwab (1990) Lesioned corticospinal tract axons regenerate in myelin-free rat spinal cord. Proc. Natl. Acad. Sci. USA 87:4130-4133

Schwab, M.E. (1991) Regeneration of lesioned CNS axons by neutralisation of neurite growth inhibitors: A short review. Paraplegia 29:294-298.

Schwab, M.E., and H. Thoenen (1985) Dissociated neurons regenerate into sciatic but not optic nerve explants in culture irrespective of neurotrophic factors. J. Neurosei. 5:2415-2423.

Shea, T.B., M.B. Beermann, and R.A. Nixon (1991) Multiple proteases regulate neurite outgrowth in NB2a/dl neuroblastoma cells. J. Neurochem. 56:842-851. 
Sidman, R.L., J.B. Angevine, and E.T. Pierce (1971) Atlas of the Mouse Brain and Spinal Cord. Cambridge: Harvard University Press.

Silverstein, R.L., and R.L. Nachman (1987) Thrombospondin-plasminogen interactions: Modulation of plasmin generation. Semin. Thromb. Hemost. 13:335-342.

Silverstein, R.L., L.L.K. Leung, P.C. Harpel, and R.L. Nachman (1984) Complex formation of platelet thrombospondin and plasminogen. $J$ Clin. Invest. 74:1625-1633.

Silverstein, R.L., P.C. Harpel, and R.L. Nachman (1986) Tissue plasminogen activator and urokinase enhance the binding of plasminogen to TSP. J. Biol. Chem. 261:9959-9965.

Silverstein, R.L., R.L. Nachman, R. Pannell, V. Gurewich, and P.C. Harpel (1990) Thrombospondin forms complexes with single-chain and twochain forms of urokinase. J. Biol. Chem. 265:11289-11294.

Snow, D.M., V. Lemmon, D.A. Carrino, A.I. Caplan, and J. Silver (1990a) Sulfated proteoglycans in astroglial barriers inhibit neurite outgrowth in vitro. Exp. Neurol. 109:111-130.

Snow, D.M., D.A. Steindler, and J. Silver (1990b) Molecular and cellular characterization of the glial roof plate of the spinal cord and optic tectum: A possible role for a proteoglycan in the development of an axon barrier. Dev. Biol. 138:359-376.

Steindler, D.A., T.F. O'Brien, E. Laywell, K. Harrington, A. Faissner, and M. Schachner (1990) Boundaries during normal and abnormal brain development: In vivo and in vitro studies of glia and glycoconjugates. Exp. Neurol. 109:35-56.
Tessler, A., B.T. Himes, J. Houle, and P.J. Reier (1988) Regeneration of adult dorsal root axons into transplants of embryonic spinal cord. J. Comp. Neurol. 270:537-548.

Thiery, J.-P., J.L. Duband, and A. Delouvee (1982) Pathways and mechanisms of avian trunk neural crest cell migration and localization. Dev. Biol. 93:324-343.

Urry, L.A., J. Ramos, M. Duquette, D.W. DeSimone, and J. Lawler (1991) Cloning, characterization, and expression of thrombospondin in Xenopus laevis embryos. J. Cell Biol. 115:295a (abstract).

Varani, J., V.M. Dixit, S.E.G. Fliegel, P.E. McKeever, and T.E. Carey (1986) Thrombospondin-induced attachment and spreading of human squamous carcinoma cells. Exp. Cell Res. 167:376-390.

Verna, J.-M., A. Gichard, and R. Saxod (1989) Influence of glycosaminoglycans on neurite morphology and outgrowth patterns in vitro. Int. J. Dev. Neurosci. 7:389-399.

Wake, M.H. (1979) Hyman's Comparative Vertebrate Anatomy, 3rd ed. Chicago: University of Chicago Press.

Werz, W., and M. Schachner (1988) Adhesion of neural cells to extracellular matrix constituents. Involvement of glycosaminoglycans and cell adhesion molecules. Dev. Brain Res. 43:225-234.

Windle, W.F. (1956) Regeneration of axons in the vertebrate central nervous system. Physiol. Rev. 36:427-440.

Wujek, J.R., and P.J. Reier (1984) Astrocytic membrane morphology: Differences between mammalian and amphibia astrocytes after axotomy. J. Comp. Neurol. 222:607-619. 